\title{
BIOLOGY OF FLOWERING, DIVERSITY OF SEXUAL TYPES AND SEED PRODUCTION IN Salsola orientalis S.G. Gmel.
}

\section{E.Z. SHAMSUTDINOVA}

W.R. Williams All-Russian Fodder Research Institute, Federal Agency of Scientific Organizations, korp. 1, ul. Nauchnii Gorodok, Lobnya, Moscow Province, 141055 Russia, e-mail daplant@mtu-net.ru Received March 21, 2016

Reproductive biology of many cultivated plants has been studied in detail whereas in newly introduced, especially arid fodder species, different aspects of flowering, pollination, reproduction, seed production, etc., should be understood. Salsola orientalis S.G. Gmel. is a dwarf semi shrub haloxerophyte plant vegetated for a long period (250-254 days), $35-55 \mathrm{~cm}$ in height, with the root system of the generic type that penetrates the soil to a depth of 5-8 m. The species is extremely drought-resistant and tolerant to salt stress so this is a valuable fodder pasture plant in the deserts of Central Asia, well eaten by sheep and camels, especially in autumn and winter. Salsola orientalis is a polymorphic species consisting of a plurality of intraspecific ecotypes, populations and biotypes which differ in environmental sustainability and fodder productivity. S. orientalis is considered promising for breeding due to intraspecific plant polymorphism on adaptiveness and productivity. Here we report the data on flowering, intraspecific diversity of sexual types in population, and seed reproductive function of $S$. orientalis. The seeds were collected in arid, geographically and environmentally distinct areas of Tajikistan, Kyrgyzstan, Uzbekistan, and sown in the Desert Karnabchul (Uzbekistan, Samarkand region, Karnab). Karnabchul is characterized by hot summers $\left(+40-45{ }^{\circ} \mathrm{C}\right.$ in June-July) and dry climate (annual precipitation of $180 \mathrm{~mm}$ with $100-250 \mathrm{~mm}$ fluctuations). The soil is grey-brown, middle-saline. This study was carried out in the nursery (each plot of $100 \mathrm{~m}^{2}$ in size) by the method of A.N. Ponomarev. The number of functionally female flowers on each plant in all populations was estimated. The type of pollination was determined in experiments with isolation of individual plants and flowers. Embryonless seeds were found among the specimen collected in different eco-geographical areas and in three tested S. orientalis varieties (Pervenets Karnaba, Solnechnyi and Salang). The seed of these varieties were divided into three fractions by size (large, medium and small) and weight of 1000 seeds. We found that the flowers in S. orientalis were cross-windpollinated. Self-pollination does not occur, since by the time of stamen appearance in bisexual flowers the pistil turns brown and dry. S. orientalis flowering begins in June and lasts until mid-July, the hottest season. However, the disclosure and the dusting of the flowers occur in the cooler morning hours (at a temperature of $25-26{ }^{\circ} \mathrm{C}$ and relative humidity of $26-65 \%$ ). In S. orientalis, self-incompatibility to avoid self-fertilization is not limited to dichogamy (i.e., non-simultaneous maturation of male and female generative structures of hermaphrodite individuals), and also combined with other adaptations to cross-pollination. These are the presence of female flowers and intermediate flowers with long stigma lobes of the pistil, and emergence of the plants with only functionally female flowers. The crosspollination in $S$. orientalis is provided by both genetic incompatibility and structure of the flower. We attributed $S$. orientalis species to trioecious plants because i) only staminate flowers, ii) hermaphrodite and pistillate flowers, and iii) only pistillate flowers were characteristic of the individuals in the population. A wide variation on embryoless seed ratio (from 0-2 \% to 98-100\%) was found in S. orientalis. Hence, selection makes it possible to increase the number of plant with low embryoless seed ratio in the population. Similar result can be achieved when using the parental forms with low percentage of embryoless seeds in breeding to obtain population with more frequent female forms. In both cases, you can get perspective parental forms for breeding varieties with low percentage of embryoless seeds and increased seed germination. Our findings are essential for development of $S$. orientalis breeding and seed production in the arid zones of Central Asia and Russia.

Keywords: Salsola orientalis, flowering, sex type, intrapopulation diversity, pollination type

The Russian scientists have notably contributed to plant reproductive biology [1-3]. Special attention was paid to embryogeny [4], polyembryony [5], genetic heterogeneity of seeds [6, 7], embryo autonomy [8], embryological bases of androclinic haploidy [9, 10]. These fundamental knowledges were the bases 
for effective technologies used to create wheat, barley, and sunflower varieties and lines [11-13], and to reproduce valuable genotypes of rare plant species for preserving their biodiversity and extending resource reproduction [14-16]. Further studies concerned the origin of different types of embryonic sacs and ovules, fertilization processes, the peculiar morphogenetic structures, seed development, and the role of heterospermia in seed reproduction [17-19]. The data elucidated the role of position control in the specialization of female gametophyte cells [20, 21], their capacity for polyembryony, and the cytoembryological mechanisms of interspecific and interlinear hybridization in economically important species of cultivated plants $[22,23]$. The achievements in reproductive biology have become the theoretical basis for effective (innovative) methods in breeding [23, 24], reproduction of biological resources [25], biodiversity conservation [26] and the biotechnologies used to massively reproduce valuable genotypes [27, 28].

Though the reproductive biology of many cultivated plants has been quite well studied, in introduced species, especially arid fodder plants, bloom biology, types of pollination, seed reproduction, and other related aspects have hardly been investigated [29]. Eastern salsola (Salsola orientalis S.G. Gmel.), a haloxerophytic semi-shrub which is widely used to restore the forage productivity of degraded pastures in the arid regions of Central Asia and Russia, is among these species [29]. Eastern salsola is a perennial plant with a root system of a universal type deeply penetrating into the soil, which possesses exceptionally high drought tolerance and tolerance to salt stress, serves as a valuable fodder plant on the arid pastures of Central Asia, is well eaten by sheep and camels, especially in autumn and winter seasons [29].

Eastern salsola is a polymorphous species consisting of a multitude of intraspecific ecotypes, populations and biotypes [29]. Its ecotypes and population forms that appeared during evolution in ecologically distinct climatic and edaphic conditions of arid zones are endowed with different adaptive and productive potentials. Such ecotype and population diversity on ecological and economically valuable traits predetermines the possibility of its improvement toward more productive drought and salt tolerant varieties.

Domestic and foreign experience of breeding forage plants indicates the success to be largely depending on the knowledge of reproductive biology. In this paper we first experimentally established that the Eastern salsola is a cross-windpollinated trioecious species. Cross-pollination is ensured by the system of genetic incompatibility and a peculiar structure of the flower. The daily and seasonal rhythms of flowering were studied under extremely harsh xerothermal conditions of the arid climate of the Central Asia, with the stages of flowers' opening and dusting described. Manifestation of the absence of corcule and its dependence on the conditions of the year were established. Based on that, we revealed a wide variability of the seeds on this trait and proposed a method for selecting plants in which the absence of corcule is low and the rate of seed germination is high.

Our aim was the study of daily and seasonal flowering rhythms, as well as estimation of the intraspecific population diversity on sexual types and seed reproduction in Eastern salsola plants in view of its breeding and seed production in arid regions of Central Asia and Russia.

Technique. Eastern salsola seeds which differed in ecological and geographical origin were collected in arid regions of Tajikistan, Kyrgyzstan, Uzbekistan, and then sown under the conditions of Karnabchul Desert, Uzbekistan, Samarkand region, Karnab) in 1998-1999. Plant reproductive biology was studied in the collection nursery as described by A.N. Ponomarev [30]. A plot size was $100 \mathrm{~m}^{2}[30]$.

Since June, the flower structure was studied, and the dynamics of flower 
opening was estimated under field conditions daily from 6.00 a.m. to 8.00 p.m. with 15-20 minute interval using loops of different magnification. Simultaneously, the temperature and the relative air humidity were recorded. Inflorescences ( 25 ones in each of 4 repetitions) and all the flowers in the lower and upper parts of the inflorescence were measured in length and width with a millimeter tape. The number of flowers per day was counted on 3 medium-sized plants of each ecotype. When studying the seasonal flowering rhythm, the number of flowers was counted daily from the beginning of flowering to the last flower appearance 4 times a day (i.e. twice from 6.00 a.m. to 12.00 noon and twice from 1.00 p.m. to 8.00 p.m.). Flowers of different sexual types were counted on all the plants of each ecotype during the entire flowering period.

The yield of normal seeds was estimated by the number of functionally female flowers on each plant in all the populations. First all the flowers, then only the female ones were counted upward along the longest second-order generative shoot. The portion of male and bisexual plants with functionally female flowers was calculated.

When studying pollination type, the whole and half of the plant were enclosed in a frame, covered on all sides by unbleached calico, and the inflorescences were isolated in parchment sacs. After maturing, the seeds were counted. To determine the rate of germless seeds in each population, the seeds of the longest generative shoot cut from each plant were crumbled into an individual paper sachet specifying the sample and plant numbers, and four samples of 100 seeds from each sachet were placed into separate bags. The bags were left in water for a day, then removed and dried. Embryos were squeezed out on the glass by light compression. The germless seed percentage was calculated for 100 seeds. In the study of germless seeds in the varieties Pervenets Karnaba and Senokosniy (All-Union Karakul Research Institute, Samarkand) and Salang (W.R. Williams All-Russian Fodder Research Institute), seeds were divided by size into the fractions (large, medium and small), and 1000 seeds of each fraction were weighted. Dependence of the germless seed occurrence on the variety genotype and plant age was studied in the collection nursery laid in 1990.

Statistical processing was carried out by dispersion and correlation analyses [31].

Results. The climate in the region is continental, with hot and dry summers and cold winters. Soils are gray-brown, sandy loamy, medium saline of chloride-sulfate type. The average annual air temperature is $+16{ }^{\circ} \mathrm{C}$, in JuneJuly in the shade it reaches $+40-45^{\circ} \mathrm{C}$, in January it drops to $-18 \ldots-20{ }^{\circ} \mathrm{C}$. The annual atmospheric precipitation amounts $180 \mathrm{~mm}$ with fluctuations of 160-250 $\mathrm{mm}$ in years. The origin of the samples is also shown in Table 1.

1. Samples (ecotypes) of Eastern salsola (Salsola orientalis S.G. Gmel.) used in the experiments, and growing conditions

\begin{tabular}{|c|c|c|c|}
\hline $\begin{array}{l}\text { Accession } \\
\text { number }\end{array}$ & Origin & Soils & $\begin{array}{l}\text { Average annual } \\
\text { precipitation, } \mathrm{mm}\end{array}$ \\
\hline k-9 & $\begin{array}{l}\text { Tajikistan, Leninabad region, settlement } \\
\text { Farab, foothill semi-desert }\end{array}$ & Light gray, loamy, slightly saline soils & 290 \\
\hline $\mathrm{k}-10$ & $\begin{array}{l}\text { Tajikistan, the town of Kanibadam, set- } \\
\text { tlement Kutkan, foothill semi-desert }\end{array}$ & $\begin{array}{l}\text { Gray, loamy, slightly saline soils of } \\
\text { sulfate-chloride type }\end{array}$ & 300 \\
\hline k-11 & $\begin{array}{l}\text { Tajikistan, the suburbs of Kurgan-Tube } \\
\text { (point 1), foothill semi-desert }\end{array}$ & Light gray, loamy, medium saline soils & 280 \\
\hline $\mathrm{k}-12$ & $\begin{array}{l}\text { Tajikistan, the suburbs of Kurgan-Tube } \\
\text { (point 2), foothill semi-desert }\end{array}$ & $\begin{array}{l}\text { Light gray soils, sandy loamy, slightly } \\
\text { saline soils }\end{array}$ & 280 \\
\hline $\mathrm{k}-13$ & $\begin{array}{l}\text { Kyrgyzstan, the suburbs of Tash-Kumyr, } \\
\text { foothill plains }\end{array}$ & Light gray, loamy-gravelly soils & 270 \\
\hline k-14 & $\begin{array}{l}\text { Uzbekistan, Namangan region, Chust } \\
\text { district, the foothill semi-desert }\end{array}$ & Light gray loamy soils & 290 \\
\hline $\mathrm{k}-15$ & $\begin{array}{l}\text { Tajikistan, Aini region, settlement Asht, } \\
\text { foothill plains }\end{array}$ & Light gray, loamy, slightly saline soils & 230 \\
\hline
\end{tabular}


k-17 Kyrgyzstan, Osh region, settlement Hay- Typical gray, loamy, slightly saline darkan, foothill semi-desert soils

Flowers of the Eastern salsola form paniculate inflorescences, one by one, are bisexual, sessile, with a spiral arrangement. A pistil appears a little bit earlier then the stamens. The calyx consists of five membranous light-green sepals, folded like in corn cob, partly overlapping one another, and having hairs. Calyx is not opening, has five free stamens, located around the base of the pistil. When the stamens appear, the anthers are considerably removed from the pistil. Stamens are the same in size. Stamen filaments are white in color, and round in cross section. Anthers are yellow, cream and pink. There is one pistil (without a post) per flower. Stigma is bilobate with a lot of papillae. Ovary has the upper location. When flowering, the calyx remains closed, resembling a cone in the neck of which the stamen filaments are grouped. In windless weather, the pollen fell on the stigma of its own pistil. On the pistil of not blossoming buds, one could see numerous papillae with pollen grains. Therefore, the pistil, even before the release of the stamens in its flower, possessed a sufficient amount of pollen from the flowers of neighboring plants.

The flowering of the Eastern salsola in the Karnabchul desert began in May and lasted until mid-July, in the hottest period when the air temperature rose to $40-41{ }^{\circ} \mathrm{C}$, and the relative humidity dropped to 6-7 \%. However, the opening and dusting of flowers occurred in the morning, at an air temperature of $25-26{ }^{\circ} \mathrm{C}$ and a relative humidity of $26-65 \%$. On the growing generative branches, along with acropeatel flowering, new buds continued to appear. In October, mature winged seeds with a developed spiral-twisted embryo appeared. The peak flowering was from the end of June to July. The flowers were protoginic, and flowering proceeded as follows. First, a bilobate, strongly pubescent stigma was seen from the perianth. On days 2 to 3 from 6.30 to 7.30 a.m., stamen filaments began to grow rapidly, carrying brightly colored anthers out of perianth. Flowering proceeded at an increasing rate, with a maximum opening of flowers at 8.309.30 a.m., and ended with the appearance of single flowers by 12.30 to 1.00 p.m. The extension of anthers and dusting occurred 40-50 minutes after the opening of floral scales. Each anther burst with a longitudinal crack and began to dust. The dusting was copious and fleeting, i.e. 10-15 minutes on warm days, 30-40 minutes in cloudy ones. The flower remained open for 5-6 hours.

We distinguished the following subphases in the flowering of Eastern salsola: the appearance of the stigma of the pistil (female subphase) (2-3 days); stamens dusting (1.0-1.5 hours); the end of flowering, the flower closing (4-7 hours). On the shoots there were flowers in different stages of flowering: some just exposed stamens, some began to dust, some intensively dusted, some were completely free from pollen, and some were closed (returned to their original state) and grouped pollen-free brown stamens in its center. Thanks to this character of blossoming, a more effective pollination and, consequently, fertilization can be achieved.

Based on flower structure and the presence of plants with a complete absence of bisexual flowers, the Eastern salsola can be referred to wind-pollinated species with cross pollination. Self-pollination did not occur, because by the time the stamens were released from the bisexual flowers, their pistil has turned brown and dry. It is known that in angiosperms the homomorphic incompatibil- 
ity of species is most common, when populations are homogeneous on the flower characteristics. Homomorphic incompatibility is reported in such large groups as the family Compositae, Cruciferae, Gramineae, Leguminosae, Rosaceae and Solanaceae; in the genus Salsola (family Chenopodiaceae) the homomorphic incompatibility has also been found $[1,4]$.

The experiments in which we isolated the whole plant or a half of the plant indicated cross-pollination in the Eastern salsola, as the seeds were not produced in both variants (Table 2).

2. Seed formation in Eastern salsola (Salsola orientalis S.G. Gmel.) plants cultivated under the conditions of wormwood-ephemeral of Karnabchul Desert $(M \pm m$, Uzbekistan, Samarkand region, arid year with average annual precipitation of $130 \mathrm{~mm})$

\begin{tabular}{l|c|c}
\hline \multicolumn{1}{c|}{ Variant } & Bud number & Normal seed number \\
\hline & N o i s o l a t i o n & \\
Whole bush & $6.60 \pm 0.60 / 100$ & $5.40 \pm 0.49 / 100$ \\
Half of bush & $4.37 \pm 0.50 / 100$ & $3.80 \pm 0.34 / 86.9$ \\
& Un e r i s o l a t i o n & 0 \\
Whole bush & $8.90 \pm 1.40 / 100$ & 0 \\
Half of bush & $2.13 \pm 0.29 / 100$ & 0 \\
Not e. The absolute values (pcs), and relative values (\%) are shown before and after the slash, respectively.
\end{tabular}

Most studies of plant reproduction are focused on self-incompatibility as the key point in the genetic control of reproduction in cross-pollinated species. However, pollination mode, the life cycle of a flower, its sexual type and structure are of no less importance in providing cross-pollination and reliable function of incompatibility systems in wind-pollinated species. Obviously, only combination of all these features makes the base for cross-pollination and, as a consequence, provides complex heterozygosity in the population $[1,12,18]$.

It is known that in some arid fodder plants [29], e.g. Kochia prostrata (L.) Schrad. and Salsola orientalis, the self-incompatibility which prevents selffertilization, is not limited to dichogamy (non-simultaneous maturation of male and female generative structures), but is combined with other adaptations to cross pollination, i.e. the presence of female and transitional forms of flowers with long lobes of the pistil stigma.

At flowering, in the Eastern salsola female plants, unlike hermaphroditous ones, the calyces were intensively green and did not open. In case of plant bisexuality, the bisexual flowers were light yellow and orange in the morning, and only after a complete pollination, when the sepals closed, they again turned greenish. These differences made it easy to detect sterile plants. In addition, the flower of a sterile plant was more like a bud having a bilobate pistil which was 1.0-1.5 times larger than the pistil of a fertile plant. In sterile forms, anthers inside the calyx did not crack and remained unclosed until the seeds ripened. Pollen coloration was from light yellow to white. The anthers of sterile plants were smaller in size and shrunken, the pollen was not spherical in shape and less in diameter as compared to fertile pollen (7-9 mm vs. 29-31 mm). Thus, a distyly may be assumed in some Eastern salsola populations, when there are plants of the first type with short stamen filaments and very elongated lobes of the pistil stigma, and those of the second type with relatively high stamen filaments, large anthers and short stigma lobes. According to available data [20, 32], heterostyly in other flowering plant species is related to dioeciousness. The short-pistil plants with short stigma lobes and the long-pistil plants (or those with oblong lobes) are analogs of male and female forms, respectively.

A significant increase in the number of pistillate flowers of the Eastern salsola was observed in a wetter year (Table 3). The lack of moisture inhibited 
the formation and development of female flowers and led to the predominance of male flowers. Optimum hydration, on the contrary, contributed to an increase in the number of female flowers and a change in the flower proportion on the plant in their favor. This led to a significant increase in the seed production per plant and, consequently, in the total seed yield.

3. Percentage of functionally female flowers in the populations of Eastern salsola (Salsola orientalis S.G. Gmel.) of different ecogeographic origin in contrasting years (collection nursery, Uzbekistan, Samarkand region)

\begin{tabular}{|c|c|c|c|c|c|}
\hline \multirow{2}{*}{$\begin{array}{l}\text { Accession } \\
\text { number }\end{array}$} & \multirow{2}{*}{$\begin{array}{l}\text { Plant density, } \\
\text { psc per } 100 \mathrm{~m}^{2}\end{array}$} & \multicolumn{2}{|c|}{$\begin{array}{l}\text { Year } 1 \text { (arid, average annual } \\
\text { precipitation of } 130 \mathrm{~mm} \text { ) }\end{array}$} & \multicolumn{2}{|c|}{$\begin{array}{l}\text { Year } 2 \text { (humid, average annual } \\
\text { precipitation of } 283 \mathrm{~mm} \text { ) }\end{array}$} \\
\hline & & on average & limits & on average & limits \\
\hline k-9 & 18 & 28 & $15-50$ & 36 & $20-55$ \\
\hline k-10 & 82 & 36 & $8-65$ & 44 & $26-58$ \\
\hline $\mathrm{k}-11$ & 82 & 41 & $10-63$ & 49 & $12-90$ \\
\hline $\mathrm{k}-12$ & 14 & 24 & $10-48$ & 34 & $19-60$ \\
\hline $\mathrm{k}-13$ & 13 & 24 & $13-41$ & 32 & $20-60$ \\
\hline $\mathrm{k}-14$ & 58 & 47 & $19-71$ & 55 & $32-86$ \\
\hline $\mathrm{K}-15$ & 26 & 36 & $15-63$ & 47 & $36-70$ \\
\hline k-16 & 66 & 47 & $9-82$ & 53 & $20-98$ \\
\hline $\mathrm{k}-17$ & 56 & 43 & $15-72$ & 52 & $30-89$ \\
\hline k-18 & 30 & 40 & $13-73$ & 44 & $28-64$ \\
\hline
\end{tabular}

As cultivars are usually more homogeneous in morphological and ecobiological characteristics, we studied the occurrence of germless seeds in three varieties of Eastern salsola. The seed size in the Pervenets Karnaba plants ranged from 6.2 (large) to $3.8 \mathrm{~mm}$ (small), and the 1000 seed weight was 7.4-5.4 g. A similar relationship between the seed size and weight was observed in the Senokosniy and Salang varieties. Fractions of middle-size seeds with intermediate 1000 seed weight value had a greater field germination rate as compared to large- and small-size seed fractions (Table 4). Mainly, this is due to the fact that in large-size fractions low-quality seeds were quite frequent, while among the relatively small seeds one could find those of good quality.

4. Seed germination in Eastern salsola (Salsola orientalis S.G. Gmel.) varieties, as influenced by seed size (collection nursery, Uzbekistan, Samarkand region, in the arid year with an average annual precipitation of $130 \mathrm{~mm}$ )

\begin{tabular}{c|l|c|c|c}
\hline Variety & Fraction & Seed size, $\mathrm{mm}$ & 1000 seed weight, g & Field seed germination, \% \\
\hline \multirow{2}{*}{ Pervenets Karnaba } & Large & 6.2 & 7.4 & 13.5 \\
& Middle & 5.3 & 6.2 & 20.0 \\
\multirow{5}{*}{ Senokosniy } & Small & 3.8 & 5.4 & 4.3 \\
& Large & 5.7 & 7.0 & 11.7 \\
\multirow{5}{*}{ Salang } & Middle & 4.6 & 6.6 & 13.5 \\
& Small & 3.8 & 5.0 & 6.8 \\
& Large & 6.5 & 8.4 & 14.5 \\
& Middle & 5.8 & 7.2 & 15.8 \\
& Small & 4.0 & 6.4 & 7.0 \\
\hline
\end{tabular}

One of the causes influencing relationship between seed size and weight, on one side, and their germless character, on the other side, could be the seeds insufficiently filled during growing and have a shrunken or shriveled appearance. This feature of seeds, despite the importance, has been little studied due to the lack of fairly simple and reliable tests.

In our experiments, the mean rate of germless seeds in the wild Eastern salsola plants varied in two years from 48 to $76 \%$ and from 46 to $64 \%$ (Table 5). In the humid year, the percentage in all the samples was 2-19\% lower than in the arid year, at that, the plants could be found in which all the seeds contained germs, while in some other plants all the seeds were germless. Plants with zero level of germless seeds belonged to k-10, k-11 and k-18 populations (Tajikistan), k-14 population (Uzbekistan) and k-13, k-17 populations (Kyrgyzstan). 
5. Percentage of germless seeds in Eastern salsola (Salsola orientalis S.G. Gmel.) plants of different ecogeographic origin in contrasting years (collection nursery, Uzbekistan, Samarkand region)

\begin{tabular}{l|c|c|c|c|c}
\hline \multirow{2}{*}{$\begin{array}{l}\text { Accession } \\
\text { number }\end{array}$} & \multirow{2}{*}{$\begin{array}{c}\text { Plant density, } \\
\text { psc per 100 } \mathrm{m}^{2}\end{array}$} & \multicolumn{2}{c|}{$\begin{array}{c}\text { Year 1 (arid, average annual } \\
\text { precipitation of 130 mm) }\end{array}$} & \multicolumn{2}{c}{$\begin{array}{c}\text { Year 2 (humid, average annual } \\
\text { precipitation of 283 mm) }\end{array}$} \\
\cline { 3 - 6 } & on average & limits & on average & limits \\
\hline k-9 & 18 & 66 & $52-85$ & 64 & $19-96$ \\
k-10 & 82 & 64 & $17-95$ & 52 & $0-100$ \\
k-11 & 82 & 69 & $27-90$ & 51 & $10-90$ \\
k-12 & 14 & 76 & $57-90$ & 57 & $26-80$ \\
k-13 & 13 & 48 & $49-77$ & 62 & $26-88$ \\
k-14 & 58 & 56 & $29-90$ & 48 & $4-98$ \\
k-15 & 26 & 69 & $29-75$ & 55 & $34-74$ \\
k-16 & 66 & 56 & $18-91$ & 52 & $8-98$ \\
k-17 & 56 & 57 & $28-98$ & 46 & $0-100$ \\
k-18 & 30 & 54 & $27-87$ & 50 & $18-84$ \\
\hline
\end{tabular}

6. Seed yield (SY, g) and germless seed rate (GLR, \%) in Eastern salsola (Salsola orientalis S.G. Gmel.) varieties during plant ageing (collection nursery, Uzbekistan, Samarkand region)

\begin{tabular}{|c|c|c|c|c|c|c|c|c|c|}
\hline \multirow{3}{*}{ Variety } & \multicolumn{9}{|c|}{ Plant age } \\
\hline & \multicolumn{2}{|c|}{1 year } & \multicolumn{2}{|c|}{2 years } & \multicolumn{2}{|c|}{3 years } & \multicolumn{2}{|c|}{8 years } & \multirow{2}{*}{$\mathrm{LSD}_{05}$} \\
\hline & SY & GLR & SY & GLR & SY & GLR & SY & GLR & \\
\hline Senokosniy & 4.7 & 41.9 & 13.7 & 49.5 & 48.7 & 52.0 & 154.7 & 57.8 & 3.9 \\
\hline Salang & 3.8 & 40.9 & 19.3 & 45.0 & 40.7 & 52.3 & 136.5 & 62.2 & 2.5 \\
\hline Pervenets Karnaba & 5.5 & 46.9 & - & - & 49.7 & 47.7 & 144.7 & 65.5 & 3.6 \\
\hline
\end{tabular}

With the age of plants, the germless seed rate elevated from 41.9 to $65.5 \%$, and the differences between extreme values in most varieties were significant (Table 6). The lowest value was found in Senokosniy variety, with $41.9 \%$ germless seeds in 1-year old plants and $57.8 \%$ germless seeds 8-year old plants. Also, individual plant seed productivity in all the varieties increased constantly, depending on age (see Table 6). In 1-year old plants, it ranged from 3.8 to $5.5 \mathrm{~g}$ per plant, and increased 26-fold and 35-fold in 8-year old plants of Pervenets Karnaba and Salang variety, respectively. An inverse relationship was found out between the seed productivity and the presence of embryo in seeds. With the rise of seed productivity as plants grew older, the germless fraction of their seeds increased.

Thus, Eastern salsola (Salsola orientalis S.G. Gmel.) plants are crosswind-pollinated. Self-pollination is not observed, since by the time the stamens are released from bisexual flowers, the pistil becomes dry. Blossoming of Eastern salsola begins in May and lasts until mid-July in the hottest period, however, the flower opening and dusting occur in the morning hours at a temperature of 25 $26^{\circ} \mathrm{C}$ and relative humidity of $26-65 \%$. Self-incompatibility, which prevents self-fertilization, is provided by dichogamy, and the presence of female and transitional flowers, as well as the plants with only functionally female flowers. Reliable cross-pollination is due to both incompatibility systems and the peculiar features of flowers. The detection of female plants among the Eastern salsola populations allows us to classify this species as trioecious, since in the population of this semi-shrub plants there are individuals with only staminate flowers, with hermaphroditic and pistillate flowers, and with the pistillate flowers only. The average amount of germless seeds varies from 48 to $76 \%$. Variability in this feature (from 0-2\% to 98-100\%) makes a wide background for section of plants with very low percent of germless seeds to increase their number in the population. A similar result can be achieved by crossing plants with low germless seed proportion to obtain populations enriched with female forms. In both cases, it is possible to create promising parental plants for breeding varieties low in germless 


\section{REFEREN C ES}

1. Embryology of flowering plants. Terminology and concepts. V. 3. Reproductive systems. T.B. Batygina (ed.). USA, Enfield (NH), 2009.

2. L'vova I.N., M u r a s h e v V.V. Vestnik Moskovskogo universiteta. Seriya 16: Biologiya, 2005, 3: 38-43 (in Russ.).

3. Anisi mova I.N., Gavrilova V.A., Ti m o fe e va G.I. Materialy Mezhdunarodnoi nauchnoprakticheskoi konferentsii «Sovremennye problemy nauchnogo obespecheniya proizvodstva podsolnechnika», posvyashchennoi 120-letiyu so dnya rozhdeniya akademika V.S. Pustovoita. [Proc. Int. Conf. «Current scientific aspects of sunflower production»]. Krasnodar, 2006: 162-174 (in Russ.).

4. B r a g i n a E.A., B at y g i n a T.B., L o o k s Yu.A. Reproduction system and repatriation in orchids. Proc. I Int. School for young scientists «Embryology and biotechnology». St. Petersburg, 2005: 33.

5. B a t y g i n a T.B. Sexyal and asexsual processes in reproductive systems of flowering plants. Acta Biologica Cracoviensia. Ser. Bot., 2006, 47(1): 51-60.

6. B a t y g i n a T.B., Vi nog r a d o va G.Yu. Ontogenez, 2007, 38(3): 1-26 (in Russ.).

7. Voronova O.N., G avrilova V.A. Botanicheskii zhurnal, 2007, 92(10): 1535-1544 (in Russ.).

8. Harrison C.J., Alve y E., H e nderso n I.R Meiosis in flowering plants and other green organisms. Journal of Experimental Botany, 2010, 61(11): 2863-2875 (doi: 10.1093/jxb/erq191).

9. An is i mova G.M., Sham rov I.I., Yakovleva O.V. Botanicheskii zhurnal, 2005, 90(10): 1499-1516 (in Russ.).

10. Kruglova N.N., B aty gi na T.B., Gorbunova V.Yu., Titova G.E., S el'd i mi ro v a O.A. Embriologicheskie osnovy androklinii pshenitsy. Atlas /Pod redaktsiei I.I. SHamrova [Embryological bases of wheat androclinia: Atlas. I.I. Shamrov (ed.)]. Moscow, 2005.

11. Sel'di mi rova O.A., T i tova G.E., Galin I.R., Kruglova N.N. Izvestiya Samarskogo NTS RAN, 2013, 15(3): 1676-1679 (in Russ.).

12. B a y g i n a T.B., T i t o v a G.E., V a s i l' e v a V.E. Innovatsii, 2007, 2: 39-46 (in Russ.).

13. Vi n o grad o va G.Yu. Botanicheskii zhurnal, 2013, 98(8): 959-974.

14. B abro A.A., An is i mova G.M., S h a m rov I.I. Rastitel'nye resursy, 2007, 43(4): 1-13 (in Russ.).

15. Torshilova A.A., Titova G.E., B atygina T.B. Female reproductive structures and seed development in Dioscorea nipponica Makino (Dioscoreaceae). Acta Biologica Cracoviensia. Ser. Bot., 2003, 45(1): 149-154.

16. Tit ov a G.E. Botanicheskii zhurnal, 2012, 97(9): 1-26 (in Russ.).

17. Vi nog radova G.Yu. Materialy Mezhdunarodnoi konferentsii «Biotekhnologiya kak instrument sokhraneniya bioraznoobraziya rastitel'nogo mira» [Proc. Int. Conf. «Biotechnology as a tool in saving flora biodiverdity»]. Simferopol, 2014: 264-265 (in Russ.).

18. Vor o nov a O.N. Integumentary embryony in CMS sunflower line. Russ. J. Dev. Biol., 2010, 41(6): 394-399 (doi: 10.1134/S106236041006007X).

19. Vor o nova O.N. Developmental of female reproductive structures and apomixes in some CMS lines of sunflower. Helia, 2013, 6: 47-60 (doi: 10.2298/HEL1358047V).

20. B atyg in a T.B., O s a d t ch i y J.V. Polyembryony: Twins - the result of vegetative propagation. The International Journal of Plant Reproductive Biology, 2013, 5(1): 21-27.

21. B r u n d r e t t M.C. Mycorrhizal associations and other means of diversity of vascular plants: understanding the global diversity of host plants by resolving conflicting information and developing reliable means of diagnosis. Plant Soil, 2009, 320(1-2): 37-77 (doi: 10.1007/s11104-008-9877-9).

22. $\mathrm{M} \mathrm{u} \mathrm{n}$ a fo Jr. J.P., G i a $\mathrm{n}$ fag $\mathrm{n}$ a T.J. Quantitative analysis of steroidal glycosides in different organsof Easter lily (Lilium longiflorum Thunb.) by LC-MS/MS. J. Agr. Food Chem., 2011, 59(3): 995-1004 (doi: 10.1021/jf1036454).

23. Ess 1 F., Biry K., Brandes D., Broennimann O., Bullock J.M., Chap man D.S., Chauvel B., Dullinger S., Fumanal B., Guisan A., Karrer G., Kazinczi G., Kueffer C., Laitung B., Lavoie C., Leitner M., Mang T., Moser D., Müller-Schärer H., Petitpierre B., Richter R., Schaffner U., S m ith M., Starfinger U., Vautard R., Vogl G., Lip pe M., Follak S. Biological flora of the British isles: Ambrosia artemisiifolia. J. Ecol., 2015, 103(4): 1069-1098 (doi: 10.1111/1365-2745.12424).

24. Habben J.E., Bao X., Bate N.J., Debruin J.L., Dolan D., Has egawa D., Helentjaris T.G., Lafitte R.H., Lovan N., Mo H., Reimann K., Schuss le r J.R. Transgenic alteration of ethylene biosynthesis increases grain yield in maize under field droughtstress conditions. Plant Biotechnol. J., 2014, 12(6): 685-693 (doi: 10.1111/pbi.12172).

25. Van Dijk H., Н a u t е и и t e N.C. Evidence of genetic change in the flowering phenology of sea beets along a latitudinal cline within two decades. J. Evolution. Biol., 2014, 27(8): 1572 1581 (doi: 10.1111/jeb.12410).

26. Dem'y a nova E.I. $O$ postanovke antiekologicheskikh issledovanii $v$ usloviyakh introduktsii. 
Mat. Mezhd. nauch. konf. «Biologicheskoe raznoobrazie. Introduktsiya rastenii» [Proc. Int., Conf. «Biodiversity. Plant introduction»]. St. Petersburg, 2011: 211-213 (in Russ.).

27. Rus sel1 S.D., G o u X., W e i X., Y u a n T. Male gamete biology in flowering plants. Biochemical Society Transactions, 2010, 38(2): 598-603 (doi: 10.1042/BST0380598).

28. B a r r e t t S.C.H. Understanding plant reproductive diversity. Philosophical Transactions of the Royal Society of London. Series B: Biological Sciences, 2010, 365(1537): 99-109 (doi: 10.1098/rstb.2009.0199).

29. Shamsutdinov Z.Sh., Kosolapov V.M., Savchenko I.V., Shamsutdinov N.Z. Ekologicheskaya restavratsiya pastbishch (na osnove novykh sortov kormovykh galofitov) [Ecorestoration of pastures using new vrieties of fodder halophytes]. Moscow, 2009 (in Russ.).

30. Po nom a r e v A.N. V knige: Polevaya geobotanika, tom 2 /Pod redaktsiei E.M. Lavrenko, A.A. Korchagina [In: Field geobotany. E.M. Lavrenko, A.A. Korchagin (eds.)]. MoscowLeningrad, 1960, V. 2: 9-19 (in Russ.).

31. D e m ' y a n o v a E.I. Vestnik Permskogo universiteta. Seriya: Biologiya, 2014, 2: 10-17 (in Russ.).

32. D o s p e k hov B.A. Metodika polevogo opyta (s osnovami statisticheskoi obrabotki rezul'tatov issledovanii) [Methods of field trials (with statistical analysis)]. Moscow, 1985 (in Russ.). 